\title{
Validity and Reliability Tests of Quality Management Football School Instruments
}

\author{
Sulistiyono Sulistiyono ${ }^{1, *}$ Wawan S. Suherman ${ }^{1,}$ Martono Martono ${ }^{1,}$ Duwi K. \\ Pambudi ${ }^{1}$
}

\author{
${ }^{I}$ Faculty of Sport Sciences, Universitas Negeri Yogyakarta, Yogyakarta, Indonesia \\ ${ }^{*}$ Corresponding author.Email: sulistiyono@uny.ac.id
}

\begin{abstract}
The aim of the research is to formulate an instrument which is used to assess the quality of football school management using a development research approach. The development procedure determines the purpose of the instrument, compiling a theoretical framework, indicators of instrument/question items, instrument items, testing the content of validity, and conducting reliability tests. The instrument was examined on nine football schools that are members of the DIY Provincial Football Federation of football school association with purposive sampling selection technique. The validity test uses the Aiken validity test technique and the reliability test uses the test-retest technique. The data analysis that will be used is qualitative and quantitative data analyses. The result of Aiken's validity test is 0.83 . The result of the reliability test is 0.842 . The quality instrument for managing football schools can be acknowledged as feasible to use. The quality instrument for managing football schools can be used by the Football Association at the Provincial or District level, which is tasked with fostering the management of football schools in their working areas.
\end{abstract}

\section{Keywords: Instrument, Quality, Management, Football School}

\section{INTRODUCTION}

Football is the most popular sport in Indonesia. The Indonesian Scale Survey (SSI) proves that 90.8 percent of Indonesians know about football. The high popularity and enthusiasm of the community towards football is, however, not in line with the achievements of the Indonesian national football team. The best accomplishment of the Indonesian national team in the FIFA rankings was in 1997 and 2001, which was ranked 87, while the worst was ranked 179 in 2015. One of the factors causing the decline in Indonesia's achievement in the senior national team at the Southeast Asian, Asian and world levels was regarding the youth player development management system. The fulfilment of human resources has not yet been optimal due to the inadequacy of trainers and funding sources. Professional human resources (HR) supports the management of an effective sports organization. Coaching young players through football schools is an early step that must be organized professionally.

Facilities and infrastructure, as well as the conditions of the coaching environment are some factors that support the goal of a coaching process to reach the greatest achievement [1]. Although the structure of football coaching has been set, the management of the football coaching organization from the central board, to the provincial associations or federation of football which have been responsible for the development of football sports are still experiencing various problems. Problems in coaching youth football players in Indonesia have not set a vision, planning, and curriculum in coaching. The data falsification cases of youth players' age also become the major crisis of this management. The next difficulty of coaching young players is the problem in competition and coach qualities, and training facilities which are considered as not optimal so that it can hinder the training process to create professional and qualified football players. Coaching young players appropriately and professionally will result in the players who have the skills, attitudes and abilities to become professional players in the future [2].

The management of football schools managed by the community or private organizations that have special attention to stimulate young people has not yet standardized the standards and guidelines that must be specifically met by the football school organizers. The management of a football school quality is a challenge that must be executed. Quality management in sports organization is an interesting topic that needs to be researched and studied. Football schools should be developed, directed, standardized or regulated in terms 
of their management through an assessment of the quality management so that the accountability for consumers of training services can be attained. The researcher aims to conduct a study that intends for developing an instrument for assessing the quality of football school management.

\section{METHODS}

The quality instrument preparation for managing football schools uses a development approach. The procedure for developing the instrument is to develop a theoretical framework, item indicators, instrument items, the validity, and reliability. The validity test is conducted by using expert validity test technique. The data obtained from the results from expert reviews were in the form of suggestions, criticisms, input and written responses related to some points that need to be evaluated regarding the assessment instrument quality for football schools' management arranged, which then described in accordance with the data collected. Assessments from experts were used as a material for revising the instrument. Then, the quantitative data received from the experts were analyzed by the technique of calculating the Validity index from Aiken.

The instrument for assessing the quality of football school management was then conducted with a reliability test with participation of 9 football schools in the association of football schools in the special region of Yogyakarta by selecting purposive sampling. The consideration for choosing the schools was because the schools are still active in the process of training services and willing to be involved in the test. The data analysis of reliability test was analyzed by finding the reliability coefficients using the Spearmen correlation test technique with SPSS 21 software assistance.

\section{RESULTS}

The arrangement of the instrument was conducted by mapping several standards for the management of training service organizations, namely: 1) curriculum standards 2) training standards 3) assessment standards 4) educator (coach) standards 5) facilities and infrastructure standards 6) management standards 7) funding standards 8) and competition standards. The instrument and question items of the instrument for assessing the quality of football school management that have been prepared by the researchers were asked for evaluation (validation) from seven experts related to the development of measuring instruments in the field of sports organization management. Suggestions from experts on the instrument statements are summarized as follows: a. The indicators that have been arranged are suitable for measuring the eight standards, but there are still inputs on several question items on certain indicators.

b. The language used is easy to understand.

c. The curriculum implementation indicators need to add one statement item which is the curriculum drafting team conducting the socialization of the curriculum that has been arranged. Of the 70 statement items prepared by the researcher after receiving evaluations from the experts, the number increased to 71 question items from the overall standards.

d. There are still errors in the writing procedure, such as writing the word "accountable" that should be written in italics and also there are words missing a few letters.

e. Experts provided feedback on the scale used and recommended a dichotomous scale (Yes-No) on the total number of statements in the instrument.

Not only were the experts asked to give feedback and evaluations, they were also asked to give a quantitative value to be used as a basis for the conclusion that the measuring instrument could be proceeded for reliability testing or whether substantial improvements should be made. The results of the assessment from seven experts on the suitability of the statement items with the concept definition were calculated using the Aiken validity index technique. The results of the management quality of 8 standart football schools can be seen in table 1 .

Table 1. Validity indeks 8 standart or component of quality management football school

\begin{tabular}{|l|c|}
\hline \multicolumn{1}{|c|}{ Dimension } & Indeks \\
\hline Curriculum Standards & 0.83 \\
\hline Training Standards & 0.75 \\
\hline Evaluation Standards & 0.92 \\
\hline Coach Standards & 0.83 \\
\hline Facilities and Infrastructure Standards & 0.92 \\
\hline Management Standards & 0.75 \\
\hline Funding Standards & 0.83 \\
\hline Competition Standards. & 0.83 \\
\hline
\end{tabular}

The results of the expert assessment showed index are 0.83 . A total of 71 items of the statement were declared valid. The total validity is 0.79 and falls into the high category. Improvements are made based on advice and input that has been given by experts. A total of 70 statement items that have been compiled by researchers after expert input, increased to 71 statement items from the entire standard. The scale improvement on the instrument is converted into a dichotomous scale (Yes-No) on the total number of statement items in the instrument. Dichotomous scale suspension is given when respondents answer Yes $=1$ and $\mathrm{No}=0$ on each instrument item. 
The reliability test measuring the quality assessment of football school management was conducted with the subject of a trial of nine football schools. Researchers conduct training on appraisers before the appraisers use measuring instruments. Equalization of perceptions of each leveling item, what the assessor should do, how to provide a score, and what evidence should exist as a basis for giving a score on each leveling item becomes training material between the research team and the assessors of the use of reliability trials. The results of the trial limited to the quality of football school management amounting to 9 football schools can be read in table 2 .

Table 2. Reliability indeks instrument quality management football school

\begin{tabular}{|c|c|c|}
\hline Football Schools & Trial I & Trial II \\
\hline Football Schools Gm & 95 & 95 \\
\hline Football Schools Su & 78 & 78 \\
\hline Football Schools Ts & 82 & 82 \\
\hline Football Schools K & 82 & 82 \\
\hline Football Schools As & 87 & 87 \\
\hline Football Schools Pt & 87 & 93 \\
\hline Football Schools Rf & 91 & 86 \\
\hline Football Schools Bj & 87 & 87 \\
\hline Football Schools Sp & 80 & 84 \\
\hline
\end{tabular}

Reliability test results on football school management quality assessment instruments are 0.842 . The reliability coefficient of 0.842 falls into a really high category. the ultimate product of the football school management quality assessment measuring tool within the sort of alignment guidelines or questions that need answers and clarifications during this device considers the results of validity tests by experts and reliability tests. the ultimate results of the football school management quality assessment instrument consists of 71 statement items divided into eight standards.

The purpose of this research is to create a quality measurement tool for football schools' management. Researchers mapped eight quality standards used as aspects to be measured in the instrument for assessing the quality of football school management as follows: 1) quality standard for curriculum 2) training 3) assessment 4) trainer 5) facilities and infrastructure 6) funding 7) organization, and 8) quality standards for competition. Similar research develop forty five items to assess service quality in sports centers in South Korea [3]. Kim set eleven indicators to measure, namely ambience, employee attitude, reliability, information, programming, personal consideration, privileges, price, ease of mind, stimulation, and convenience. The result of the validity content using the Validity index of aiken was 0.79 and the reliability coefficient was 0.842 . The instrument was acknowledged suitable for use to evaluate the quality of football schools' management.

The measurement tool for the quality of football schools' management is in accordance with studies in the management of sports organizations as a service organization to consumers. Marketing activities in professional sports clubs such as ticket sales, merchandising, course programs and sponsorships all depend on satisfied users, fans and partners [4]. The special characteristics of sports products and services require managers of sports organizations to focus on service quality if they want to receive the customers' satisfaction and loyalty. As is often stated in marketing theories, sports products consist of the main product and the development of the main product, [5] [6].

The indicator framework set by the researcher is related to the problem of quality assessment in organizations in accordance with several other studies that have been carried out, for example research that focuses on identifying dimensions of quality in services in certain fields, such as fitness services, recreational sports services, and recreational services. The five dimensions of fitness services as measured by their Fitness Services Attributes Scale (SAFS) [7]. The dimensions set are service professionalism, consumers, peripherals, facilities, and secondary services. While concepts related to quality in service are meaningful to all types of organizations, public and non-profit organizations create additional quality indicators due to their mandate to serve society as a whole in addition to the clients themselves. The six dimensions of quality in public health care organizations are shown in table $3,[7]$.

Table 3. Dimensions of quality in public and nonprofit organisations

\begin{tabular}{|c|c|}
\hline Dimension & Description \\
\hline Access to Services & $\begin{array}{c}\text { ease of accessing the system, physical } \\
\text { accessibility, waiting time }\end{array}$ \\
\hline Relevance to Need & $\begin{array}{c}\text { relevant for the whole community and its } \\
\text { needs }\end{array}$ \\
\hline Effectifness & $\begin{array}{c}\text { effective for individual consumers } \\
\text { including technical competence }\end{array}$ \\
\hline Equity (Fairness) & $\begin{array}{c}\text { available equally to all in relation to need } \\
\text { including physical and interpersonal } \\
\text { aspects, and the ethical nature of treatment } \\
\text { procedures }\end{array}$ \\
\hline $\begin{array}{c}\text { Efficiency and } \\
\text { Economy }\end{array}$ & $\begin{array}{c}\text { relating to outcome to costs and resource } \\
\text { use }\end{array}$ \\
\hline
\end{tabular}

The design of a measuring instrument with eight standards that must be achieved by football training 
service managers is in accordance with marketing theory where football schools' managers affect customer satisfaction by manipulating service aspects identified as products under the control of football schools' managers or principals. Football schools' services have the main product of coaching services, but it is also important to control the quality of other services, such as the quality of infrastructure and administrative services to influence customer satisfaction by offering high-quality services. In order to offer such high-quality services to customers, managers of sports organizations must periodically evaluate their quality services. The framework developed in setting out the instrument in this study is to develop assessment standards or indicators according to the type of service so that two contrasting point of views as the basis for the quality assessment can be obtained [8], [9]. The "gap" theory suggests that service quality as perceived by consumers stems from comparing what they feel service managers should offer with perceived quality of organizational management [10], [11], [12].

The effects of developing a quality measurement tool for football schools' management is that the manager must design and ensure the prime service quality that can be experienced by the customers, employees and other stakeholders. Three basic components of TQM, namely: 1) focusing on (satisfaction), 2) continuous improvement (innovation): all processes are continuously refined and improved to get better service to the customers, 3 ) engagement (commitment): all employees participate and engage to enhance the rate of services provided to the customers [13], [14].

Aspects of organizational performance management system in human resources, in this study, the most important is the trainer. Another supportive study is the role that human resource management should play in determining the overall success or failure in relation to organizational performance [15], [16], [17], [18] . The measurement of performance is an integral component of the overall management of the organization and it must be integrated so as to provide the information desired by the manager [19]. Four necessary components in a management quality measurement system decide what to measure [20], how to measure it [21]; interpreting data communicating the results, [22]. Opportunities for improving the instrument resulted from this study are the level of satisfaction of stakeholders with football schools' services. Stakeholder satisfaction has been the most consistent determinant of the quality of sports organizational management proposed in literature. Organizational management performance can be described by the level of satisfaction experienced by organizational stakeholders [23], [24], [25].
The assessment of the quality of football schools' management is one of the efforts to improve the quality in the process of managing football schools' performance. Managing a football school requires supervision based on the quality of the management system. The quality management system (Total Quality Management) is a philosophy of continuous improvement that can provide a set of practical tools to every educational institution in meeting the needs, desires, and expectations of its current and future customers, [11].

The assessment of the quality of football schools' management conducted through the quality management system approach is expected to be able to create good quality football schools' management. Every football school will try to meet every standard that has been prepared in the quality assessment instrument for managing football schools. The quality standards that have been set are a reflection of the whole conditions and characteristics of inputs, processes, outputs, outcomes, and impacts, or the performance of football schools' management. Football school is one of the important forums in encouraging the youth in football so that special attention needs to be given to the quality of its management by both national and regional football federations.

\section{CONCLUSION}

Based on the results of the research and discussion, the conclusions drawn show that from the 70 question items proposed by the researcher, the number increased to 71 question items based on the feedback from the experts. Seventy-one (71) question items were categorized as valid in the number of service indicators. The total validity is 0.83 . The results of the instrument reliability test obtained the degree of reliability coefficient of 0.842 . The instrument for assessing the quality of football schools' management is appropriate because it has met the requirements of the validity and reliability tests. National and regional football associations can formulate policies related to the quality of football schools' management by implementing a football management quality assessment developed by the researcher.

\section{ACKNOWLEDGMENT}

The author would like to thank UNY for funding this group's research.

\section{REFERENCES}

[1] W. A. Nugroho, "Pembinaan Prestasi Olahraga Sepakbola Di Pusat Pendidikan Dan Latihan Putra Batang," JUARA J. Olahraga, vol. 2, no. 2, p. 162, 2017, 
doi: $10.33222 /$ juara.v2i2.43.

[2] I. F. Ani and H. Suprayitno, "Partisipasi Kelompok Sepakbola PSP Dalam Upaya Pembinaan Anak Usia Dini Untuk Kemajuan Olahraga Di Desa Pasiraman," Translitera J. Kaji. Komun. dan Stud. Media, vol. 5, no. 2, pp. 25-35, 2018, doi: $10.35457 /$ translitera.v5i2.361.

[3] D. Kim and S. Y. Kim, "QUESC: An Instrument for Assessing the Service Quality of Sport Centers in Korea," J. Sport Manag., vol. 9, no. 2, pp. 208-220, 2016, doi: 10.1123/jsm.9.2.208.

[4] J. Mattsson, "Improving Service Quality in Person-toPerson Encounters: Integrating Findings from a Multidisciplinary Review," Serv. Ind. J., vol. 14, no. 1, pp. 4561, 1994, doi: 10.1080/02642069400000004.

[5] V. Ratten, "Sport-based entrepreneurship: Towards a new theory of entrepreneurship and sport management." International Entrepreneurship and Management Journal , pp. 57-69, 2010.

[6] D. Shilbury, H. Westerbeek, S. Quick, D. Funk, A. Karg, and L. Dickler, "Strategic Sport Marketing," Sport Manag. Rev., vol. 18, no. 4, pp. 627-628, 2015, doi: 10.1016/j.smr.2014.09.004.

[7] P. Chelladurai and K. Chang, "Targets and Standards of Quality in Sport Services," Sport Manag. Rev., vol. 3, no. 1, pp. 1-22, 2000, doi: 10.1016/S1441-3523(00)70077-5.

[8] D. Eldridge, C. Pulling, and M. Robins, "Visual exploratory activity in youth soccer players," J. Hum. Sport Exerc., vol. 8, no. 2, pp. 486-487, 2013, doi: $10.4100 /$ jhse.

[9] A. Parasuraman, V. A. Zeithaml, and L. L. Berry, "Reassessment of Expectations as a Comparison Standard in Measuring Service Quality: Implications for Further Research," J. Mark., vol. 58, no. 1, p. 111, 1994, doi: $10.2307 / 1252255$.

[10] J. J. Zhang, D. Connaughton, and C. E. Vaughn, "The role of special programmes and services for season ticket holders in predicting game consumption," Int. J. Sport. Mark. Spons., vol. 6, no. 2, pp. 22-39, 2004, doi: 10.1108/ijsms-06-02-2004-b005.

[11] A. Ghobadian and D. N. Gallear, "Total quality management in SMEs," Omega, vol. 24, no. 1, pp. 83106, 1996, doi: 10.1016/0305-0483(95)00055-0.

[12] J. Samal, "Effective Factors Influencing Performance Management System in Commercial Bank: An Exploratory Analysis," Int. J. Manag. Stud., vol. VI, no. 1(6), p. 12, 2019, doi: 10.18843/ijms/v6i1(6)/02.

[13] I. O. Boyle, “A p m p n - s o: a c s n z," vol. 16, no.
April, pp. 1-24, 2015.

[14] J. C. Groth, "Total quality management: Perspectives for leaders," TQM Mag., vol. 7, no. 3, pp. 54-59, 1995, doi: $10.1108 / 09544789510087788$.

[15] T. Byers, "Using critical realism: A new perspective on control of volunteers in sport clubs," Eur. Sport Manag. Q., vol. 13, no. 1, pp. 5-31, 2013, doi: $10.1080 / 16184742.2012 .744765$.

[16] G. Cuskelly, "Volunteer retention in community sport organisations," Eur. Sport Manag. Q., vol. 4, no. 2, pp. 59-76, 2004, doi: 10.1080/16184740408737469.

[17] T. Schlesinger, B. Egli, and S. Nagel, "“Continue or terminate?' Determinants of long-term volunteering in sports clubs," Eur. Sport Manag. Q., vol. 13, no. 1, pp. 32-53, 2013, doi: 10.1080/16184742.2012.744766.

[18] P. Wicker and K. Hallmann, "A multi-level framework for investigating the engagement of sport volunteers," Eur. Sport Manag. Q., vol. 13, no. 1, pp. 110-139, 2013, doi: $10.1080 / 16184742.2012 .744768$.

[19] I. O'Boyle and D. Hassan, "Performance management and measurement in national-level non-profit sport organisations," Eur. Sport Manag. Q., vol. 14, no. 3, pp. 299-314, 2014, doi: 10.1080/16184742.2014.898677.

[20] M. Kennerley and A. Neely, "A framework of the factors affecting the evolution of performance measurement systems," Int. J. Oper. Prod. Manag., vol. 22, no. 11, pp. 1222-1245, 2002, doi: 10.1108/01443570210450293.

[21] J. Vakkuri and P. Meklin, "The impact of culture on the use of performance measurement information in the university setting," Manag. Decis., vol. 41, no. 8, pp. 751-759, 2003, doi: 10.1108/00251740310496260.

[22] M. Franco-Santos et al., "Towards a definition of a business performance measurement system," Int. J. Oper. Prod. Manag., vol. 27, no. 8, pp. 784-801, 2007, doi: $10.1108 / 01443570710763778$.

[23] E. Bayle and A. Madella, "Development of a taxonomy of performance for national sport organizations," Eur. J. Sport Sci., vol. 2, no. 2, pp. 1-21, 2002, doi: 10.1080/17461390200072205.

[24] L. Robinson, "Customer Expectations of Sport Organisations," Eur. Sport Manag. Q., vol. 6, no. 1, pp. 67-84, 2006, doi: 10.1080/16184740600799204.

[25] D. Papadimitriou and P. Taylor, "Organisational Effectiveness of Hellenic National Sports Organisations: A Multiple Constituency Approach," Sport Manag. Rev., vol. 3 , no. 1 , pp. $23-46,2000$, doi: 10.1016/S14413523(00)70078-7. 